Огляди літератури, оригінальні дослідження, погляд на проблему

УДК 616.12-008.46/-005.4+616.379-008.64]-06:616.126-08

DOI 10.11603/1811-2471.2017.v1.i3.7954

\title{
ЕФЕКТИВНІСТЬ КОМПЛЕКСНОЇ СТАНДАРТНОЇ ТЕРАПІЇ ІЗ ЗАСТОСУВАННЯМ АЛЬФА-ЛІПОЄВОЇ КИСЛОТИ У ХВОРИХ НА СТАБІЛЬНУ ІШЕМІЧНУ ХВОРОБУ СЕРЦЯ ІЗ СУПУТНІМ ЦУКРОВИМ ДІАБЕТОМ 2 ТИПУ
}

\author{
○Н. І. Ярема, А. І. Хоміцька, І. П. Савченко, Л. В. Радецька, Л. В. Наумова, О. І. Коцюба \\ ДВНЗ «Тернопільський державний медичний університет імені І. Я. Горбачевського МОз Украӥни»
}

РЕЗЮМЕ. Застосування альфа-ліпоєвої кислоти (а-ЛК) у хворих на стабільну ішемічну хворобу серця (IXC) із діабетичною полінейропатією нижніх кінцівок (ДПНК) значно підвищує кисневе забезпечення периферійних тканин.

Метою роботи було підвищити ефективність комплексного лікування дПнК у хворих на стабільну IXС із супутнім ЦД 2 типу.

Матеріал і методи. Обстежено 54 хворих на стабільну IXC із супутнім ЦД 2 типу, ускладненим ДПнК. Проведено ехокардіоскопію, оцінку неврологічних симптомів, дослідження чутливостей, а також оцінку параметрів оксигенації артеріальної і венозної крові. Усі хворі отримували стандартну терапію стабільної IXC та а-ЛК у добовій дозі 600 мг/добу протягом 1 місяця.

Результати. Комплексне застосування а-ЛК із стандартною терапією стабільної IXC значно покращує неврологічну симптоматику ДПНК та кисневе забезпечення тканин нижніх кінцівок.

КлючовІ СловА: стабільна ішемічна хвороба серця; діастолічна дисфункція лівого шлуночка; цукровий діабет 2 типу; діабетична полінейропатія нижніх кінцівок; оксигенація артеріальної та венозної крові; альфаліпоєва кислота.

Вступ. Поширеність стабільної ішемічної хвороби серця (IXC) серед дорослого населення України складає близько $24 \%$, а серед осіб працездатного віку - близько $10 \%$ [1]. Окрім того, впродовж останніх років зростає і частота поєднаного перебігу IXC із супутнім цукровим діабетом (ЦД) 2 типу, оскільки серцево-судинні захворювання і летальність, насамперед внаслідок IXC, в групі пацієнтів із ЦД 2 типу вищі у 2-5 разів [4].

Ураження периферійної нервової системи, як хронічне ускладнення ЦД, трапляється у $40-60 \%$ випадків і проявляється у вигляді діабетичної полінейропатії нижніх кінцівок (ДПНК) $[3,6]$. При вперше виявленому ЦД 2 типу ДПНК діагностується у 15,3 \% випадків, при тривалості ЦД від одного до п'яти років - у 34,2 \% хворих, при “стажі» ЦД 5-10 років - у 55,4 \%, а при тривалості захворювання понад 10 років частота полінейропатії сягає $76,9 \%[1,7]$.

Відомо, що в ефективності транспортування кисню до периферійних тканин організму та його компенсаторній спроможності провідна роль належить функціональній здатності серцево-судинної системи, ії систолічній та діастолічній функціям [2]. Проте на сьогодні недостатньо даних щодо особливостей цих порушень при поєднанні стабільної IXC із ЦД 2 типу, тому пошук відповідної медикаментозної корекції кисневого забезпечення периферійних тканин при коморбідності IXC та ЦД 2 типу $є$ актуальною темою.

Матеріал і методи дослідження. Обстежено 54 хворих на стабільну IXC із діастолічною дисфункцією лівого шлуночка (ДДлШ) та супутнім
ЦД 2 типу. Контрольну групу склали 30 практично здорових осіб, зіставних з обстеженими хворими за віком та статтю. Крім загальноклінічних методів обстеження кардіологічних та ендокринологічних хворих усім пацієнтам було проведено двовимірну ехокардіоскопію в В-режимі з аналізом показників ДДлШ, оцінку неврологічних симптомів як за окремими симптомами, так і за сумою балів за шкалою NDS (Neuropathy Disability Score), дослідження колінного, ахілового рефлексів та тактильної, больової, температурної, вібраційної, пропріоцептивної чутливостей, а також оцінку параметрів оксигенації артеріальної і венозної крові методом пульсоксиметрії та оксиметрії (сатурації артеріальної крові Sa. ${ }_{2}$, сатурації венозної крові Sv. ${ }_{2}$, вмісту кисню в артеріальній крові Са.О вмісту кисню у венозній крові $\mathrm{Cv}_{2} \mathrm{O}_{2}$, об'єму спожитого кисню тканинами нижніх кінцівок $\mathrm{Da} . \mathrm{O}_{2}-$ Dv. $\mathrm{O}_{2}$ ).

У всіх хворих на стабільну IXC із коморбідним ЦД 2 типу діагностовано ДДЛШ. Помірно виражену хронічну двобічну сенсомоторну полінейропатію нижніх кінцівок (індекс за шкалою NDS 4-2 балів) діагностовано у всіх обстежених пацієнтів із стабільною IXC та супутнім ЦД 2 типу.

Усі хворі отримували комплексну стандартну антиішемічну терапію стабільної IXC (бета-адреноблокатори, нітрати, ацетилсаліцилову кислоту, статини, інгібітори ангіотензинперетворювального ферменту або антагоністи рецепторів ангіотензину II) та додатковий курс лікування із застосуванням альфа-ліпоєвої кислоти (а-ЛК) у добовій дозі 600 мг/добу протягом 1 місяця. 
Огляди літератури, оригінальні дослідження, погляд на проблему

Статистичну обробку отриманих результатів проводили за допомогою пакета статистичних програм "Statistica 6.0" (StatSoft, Inc., USA) з визначенням статистичної значимості показників 3 прийнятим рівнем ймовірності похибки не вище $5 \%(p<0,05)$, розрахунком середнього арифметичного значення (М), середньоквадратичного відхилення (б) та середньої похибки (m). Для дослідження взаємозв'язків між показниками було проведено кореляційний аналіз з використанням коефіцієнта лінійної кореляції Пірсона (г).

Результати й обговорення. У обстежених хворих неврологічна симптоматика ДПНК проявлялася значним затерпанням, онімінням нижніх кінцівок, відчуттям "повзання мурашок» та мерзлякуватості ніг у 100 \% хворих, біль та па- рестезії нижніх кінцівок турбували 78,2 \% паці$\epsilon$ нтів.

При дослідженні рефлекторного стану у 99,4 \% обстежених виявлено зниження колінного та ахілового рефлексів, а оцінка чутливості показала значне зниження вібраційної, тактильної, больової, температурної та пропріоцептивної чутливостей у $100 \%$ хворих на стабільну IXC із ДДЛШ та супутнім ЦД 2 типу, ускладненим ДПНК, порівняно із даним неврологічним статусом у здорових осіб.

У обстежених хворих на стабільну IXC із супутнім ЦД 2 типу виявлено ознаки ДДлШ за релаксаційним типом, що проявлялися зниженням співвідношення максимальної швидкості раннього та пізнього діастолічного наповнення E/A на 26,1 \% $(p<0,01)$, порівняно з групою контролю (рис. 1).
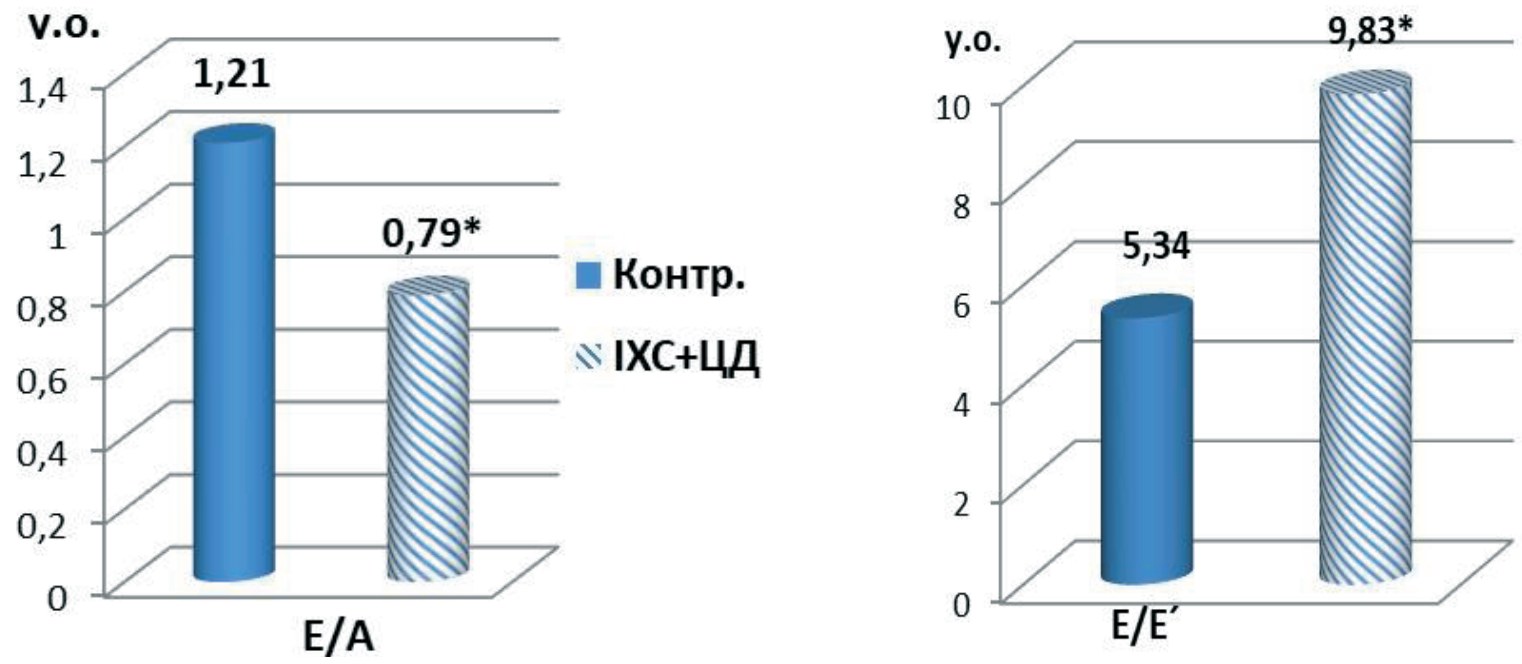

Рис. 1. Показники діастолічної функції лівого шлуночка у хворих на стабільну IXC із супутнім ЦД 2 типу.

Співвідношення максимальної швидкості раннього діастолічного наповнення до максимальної швидкості руху фіброзного кільця мітрального клапана в фазу раннього наповнення лівого шлуночка $E / E^{\prime}$ було вищим на $30,4 \%(p<0,01)$, порівняно з групою контролю. Зниження співвідношення E/A та зростання E/E` $\epsilon$ свідченням підвищення жорсткості міокарда та прогресування діастолічної серцевої недостатності у хворих на стабільну IXC із супутнім ЦД 2 типу.

Аналізуючи дані параметрів оксигенації артеріальної і венозної крові у хворих на стабільну IXC із ДДлШ та ЦД 2 типу, ускладненим помірно вираженою ДПНК до початку лікування, було виявлено порушення кисневого забезпечення тканин нижніх кінцівок. Зокрема, це проявлялося достовірним зниженням значення Sv. $\mathrm{O}_{2}$ на $16,8 \%(p<0,05)$, порівняно з групою контролю. Вміст кисню в ар-

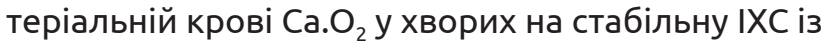
ДДЛШ та супутнім ЦД 2 типу був нижчим на 16,2 $(p<0,05)$, а значення Cv. $\mathrm{O}_{2}-$ на $18,1 \%(p<0,01)$ нижчим, порівняно із здоровими особами.

Відповідно, об'єм спожитого кисню тканинами нижніх кінцівок Da.O2-Dv.O ${ }_{2}$ був нижчим на $10,9 \%(p<0,05)$, порівняно з групою контролю. Виявлені зміни $\epsilon$ свідченням недостатнього насичення киснем тканин нижніх кінцівок в результаті утруднення трансвенозного кровотоку у хворих на стабільну IXC із супутнім ЦД 2 типу, ускладненим ДПНК.

При коморбідній патології, а саме при наявності ЦД 2 типу, зниження об'єму кисню, який транспортується до тканин нижніх кінцівок, супроводжується зменшенням об'єму кисню, спожитого тканинами нижніх кінцівок. Таким чином прогресує феномен кисневої заборгованості, i, на фоні клінічних ознак ДДЛШ зниження вмісту кисню та насиченості ним венозної крові можуть слугувати критеріями прогресування основної та коморбідної патології. 
Огляди літератури, оригінальні дослідження, погляд на проблему

Встановлено пряму кореляцію між зниженням співвідношення E/A та значення Da. $\mathrm{O}_{2}-\mathrm{Dv}_{\mathrm{O}} \mathrm{O}_{2}$ $(r=0,41, p<0,05)$, а також обернену кореляцію між зростанням співвідношення E/E' та зниженням значення Da. $\mathrm{O}_{2}-\mathrm{Dv} . \mathrm{O}_{2}(r=-0,37, \mathrm{p}<0,05)$ у хворих на стабільну IXC із ДДлШ та супутнім ЦД 2 типу, що свідчить про порушення кисневого забезпечення тканин організму при підвищенні жорсткості міокарда в даної категорії хворих.

Наступним етапом нашої роботи була оцінка ефективності впливу а-ЛК на вираженість неврологічних симптомів ДПНК, на різні види чутливості та стан рефлексів у хворих на стабільну IXC із ДДЛШ та супутнім ЦД 2 типу, ускладненим помірно вираженою ДПНК. Обстежені хворі отримали курс лікування а-ЛК внутрішньовенними інфузіями в дозі 600 мг/добу протягом 10 днів з подальшим пероральним прийомом препарату в тій же дозі протягом 20 днів.
Нами встановлено покращання неврологічного статусу у хворих на стабільну IXC із ДПНК після курсу лікування а-ЛК. Вираженість симптомів ДПНК після даної терапії була значно меншою, ніж до лікування. Зокрема, у 99,2 \% пацієнтів відмічено значне зниження затерпання, оніміння нижніх кінцівок, відчуття "повзання мурашок», мерзлякуватості ніг, а болі та парестезії нижніх кінцівок зменшились у 88,6 \% обстежених. У 98,6 \% пацієнтів, котрі отримували курс лікування а-ЛК, відмічено покращання колінного та ахілового рефлексів, а також позитивну динаміку при оцінці вібраційної, тактильної больової, температурної та пропріоцептивної чутливостей, порівняно із даним неврологічним статусом до лікування.

Показники оксигенації артеріальної і венозної крові у хворих на стабільну IXC із ДДЛШ та супутнім ЦД 2 типу, ускладненим помірно вираженою ДПНК, після курсу лікування а-ЛК достовірно зростали (табл. 1).

Таблиця 1. Показники оксигенації артеріальної та венозної крові у хворих на стабільну IXC

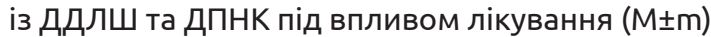

\begin{tabular}{|c|c|c|c|c|}
\hline Показники & $\begin{array}{c}\text { Група контролю, } \\
\text { n=30 }\end{array}$ & $\begin{array}{c}\text { Хворі на IXC та ЦД } \\
\text { до лікування, } \\
\text { n=54 }\end{array}$ & $\begin{array}{c}\text { Хворі на IXС та ЦД } \\
\text { після лікування, } \\
\text { n=54 }\end{array}$ & $P_{1-2}$ \\
\hline Sa.O ${ }_{2}$, мл·л ${ }^{-1}$ & $98,40 \pm 0,41$ & $94,88 \pm 0,32 *$ & $98,32 \pm 0,43$ & $<0,05$ \\
\hline $\mathrm{Sv}_{2}, \mathrm{O}_{2}$ мл·л л $^{-1}$ & $149,20 \pm 0,62$ & $124,31 \pm 0,55^{*}$ & $144,12 \pm 0,43^{*}$ & $<0,05$ \\
\hline $\mathrm{Ca} . \mathrm{O}_{2}$, мл·л ${ }^{-1}$ & $70,31 \pm 0,33$ & $58,94 \pm 0,41 *$ & $68,54 \pm 0,26 *$ & $<0,05$ \\
\hline Cv.O ${ }_{2}$, мл·л ${ }^{-1}$ & $98,33 \pm 0,62$ & $80,71 \pm 0,31 *$ & $88,11 \pm 0,42 *$ & $<0,05$ \\
\hline Da.O ${ }_{2}-\mathrm{Dv} . \mathrm{O}_{2}$, мл.л ${ }^{-1}$ & $50,96 \pm 0,66$ & $46,91 \pm 0,70$ & $50,10 \pm 0,53$ & $<0,05$ \\
\hline
\end{tabular}

Примітки: 1. * - достовірність різниці показників порівняно з контролем;

2. $p_{1-2}-$ достовірність різниці показників порівняно з даними до лікування.

Сатурація артеріальної крові Sa.О маної терапії зростала на $5,1 \%(p<0,05)$, а рівень Sv. $\mathrm{O}_{2}$ - на 20,6\% (p<0,01), порівняно з аналогічними показниками до лікування. Са.О ${ }_{2}$ після проведеного лікування був дещо вищим, порівняно 3 його значенням до лікування, а $\mathrm{Cv}_{\text {. }} \mathrm{O}_{2}$ достовірно зріс на $9,1 \%(p<0,05)$, порівняно з його рівнем до початку лікування. Відповідно, об'єм спожитого кисню тканинами нижніх кінцівок $\mathrm{Da}_{2} \mathrm{O}_{2}-\mathrm{Dv} . \mathrm{O}_{2}$ у хворих на стабільну IXC із ДДЛШ та супутнім ЦД 2 типу, ускладненим ДПНК, після курсу лікування а-ЛК став вищим на $10,1 \%(p<0,05)$.

Отже, застосування у складі комплексної терапії курсу а-ЛК у хворих на стабільну IXC із ДДЛШ та супутнім ЦД 2 типу, ускладненим помірно вираженою ДПНК, сприяло значному зниженню вираженості невропатичних симптомів, покращанню больової, тактильної, вібраційної, пропріоцептивної, температурної чутливостей, зниженню больового синдрому в нижніх кінцівках та посиленню кисневого забезпечення тканин нижніх кінцівок.
Висновки. 1. У хворих на стабільну IXC із супутнім ЦД 2 типу, ускладненим ДПНК, виявлений взаємозв'язок між ДДЛШ та змінами кисневого забезпечення периферійних тканин, що підтверджується встановленою кореляцією між Е/А та Da. $\mathrm{O}_{2}-\mathrm{Dv} . \mathrm{O}_{2}(r=0,41, \mathrm{p}<0,05)$, оберненою кореляці$\epsilon ю$ між E/E' та Da. $\mathrm{O}_{2}-\mathrm{Dv} . \mathrm{O}_{2}(r=-0,37, \mathrm{p}<0,05)$.

2. Додаткове застосування до комплексної стандартної терапії хворих на стабільну IXC із супутнім ЦД 2 типу з проявами полінейропатії нижніх кінцівок а-ліпоєвої кислоти покращує клінічний перебіг діастолічної серцевої недостатності та запобігає прогресуванню полінейропатії нижніх кінцівок.

3. Курс лікування із застосуванням а-ліпоєвої кислоти достовірно покращує показники оксигенації артеріальної і венозної крові із зростанням об'єму спожитого кисню тканинами нижніх кінцівок на $10,1 \%(p<0,05)$ у хворих на стабільну IXC в умовах коморбідності з ЦД 2 типу, ускладненим ДПНК. 
Огляди літератури, оригінальні дослідження, погляд на проблему

\section{ЛІТЕРАТУРА}

1. Маньковський Б. М. Лікування діабетичної полінейропатії: яка доказова база? / Б. М. Маньковський // Ліки України. - 2013.- № 10 (156). - С. 30-32.

2. Паньків В. І. Ризик загальної і серцево-судинної смертності, основних серцево-судинних подій у хворих на цукровий діабет 2 типу залежно від вибору терапії після встановлення діагнозу / В. І. Паньків, Л. А. Хуторська // Буковинський медичний вісник. - 2013. - № 1. - С. 80-83.

3. Паньків В. І. Управління діабетичною нейропатією: орієнтація на пацієнта / В. І. Паньків // Міжнародний ендокринологічний журнал. - 2014. - № 3 (51). - С. 47-48.

4. Уніфікований клінічний протокол первинної, вторинної (спеціалізованої) та третинної (високоспеціалізованої) медичної допомоги. Стабільна ішемічна хвороба серця. - Київ, 2015. - С. 8-9.

\section{REFFERENCES}

1. Mankovskyi, B.M., (2013). Likuvannia diabetychnoi polineiropatii: yaka dokazova baza? [Treatment of diabetic polyneuropathy: what is the evidence base?]. Liky Ukrainy Medicine of Ukraine, 10 (156), 30-32 [in Ukrainian].

2. Pankiv, V.I., \& Khutorska, L.A. (2013). Ryzyk zahalnoi i sertsevo-sudynnoi smertnosti, osnovnykh sertsevo-sudynnykh podii u khvorykh na tsukrovyi diabet 2 typu zalezhno vid vyboru terapii pislia vstanovlennia diahnozu [Risk overall and cardiovascular mortality, major cardiovascular events in patients with type 2 diabetes, depending on the choice of therapy after diagnosis]. Bukovynskyi medychnyi visnyk - Bukovyna Medical Journal, 1, 80-83 [in Ukrainian].

3. Pankiv, V.I., (2014). Upravlinnia diabetychnoiu neiropatiieiu: oriientatsiia na patsiienta [Management of diabetic neuropathy: patient's orientation]. Mizhnarodnyi endokrynolohichnyi zhurnal - International Endocrinology Journal, 3 (51), 47-48 [in Ukrainian].

4. Unifikovanyi klinichnyi protokol pervynnoi, vtorynnoi (spetsializovanoi) ta tretynnoi (vysokospetsializovanoi) medychnoi dopomohy. Stabilna ishemichna khvoroba sertsia
5. Фомина И. Г. Диагностика микроциркуляторных нарушений у больных с сахарным диабетом 2 типа и ишемической болезнью сердца / И. Г. Фомина, Б. Б. Салтыков, Т. В. Королева // Клиническая медицина. - 2014. T. 82, № 2. - C. 36-39.

6. Wu S. Benfotiamine alleviates diabetes-induces cerebral oxidative damage independent of advanced glycation end-product, tissue factor / S. Wu, J. Ren // Neurosc. Lett. - 2014. - Vol. 394. - P. 158-162.

7. Guidelines on diabetes, pre-diabetes and cardiovascular disease: executive summary. The Task Force on Diabetes and Cardiovascular Diseases of the European Society of Cardilogy (ESC) and of the European Association for the Study of Diabetes (EASD) // European Heart Journal. - 2007. - Vol. 28. - P. 88-136.

[Unified clinical protocol of primary, secondary (specialized) and tertiary (highly specialized) medical aid. Stable ischemic heart disease]. Kyiv [in Ukrainian].

5. Fomina, I.C., Saltikov, B.B., Koroleva, T.V. (2014). Diagnostika mikrotsyrkulyatornykh narusheniy u bolnykh s sakharnym diabetom 2 tipa i ishemicheskoy boleznyu serdtsa [Diagnosis of microcirculatory disorders in patients with type 2 diabetes mellitus and coronary heart disease]. Klinicheskaya meditsyna - Clinical Medicine, 82 (2), 36-39 [in Russian].

6. Wu, S., \& Ren, J., (2014). Benfotiamine alleviates diabetes-induces cerebral oxidative damage independent of advanced glycation end-product, tissue factor. Neurosc. Lett., 394, 158-162.

7. (2007). Guidelines on diabetes, pre-diabetes and cardiovascular disease: executive summary. The Task Force on Diabetes and Cardiovascular Diseas of the European Society of Cardilogy (ESC) and of the European Association for the Study of Diabetes (EASD). European Heart Journal, 28, 88-136.

\title{
ЭФФЕКТИВНОСТЬ КОМПЛЕКСНОЙ СТАНДАРТНОЙ ТЕРАПИИ С ИСПОЛЬЗОВАНИЕМ АЛЬФА-ЛИПОЕВОЙ КИСЛОТЫ У БОЛЬНЫХ СО СТАБИЛЬНОЙ ИШЕМИЧЕСКОЙ БОЛЕЗНЬЮ СЕРДЦА С СОПУТСТВУЮЩИМ САХАРНЫМ ДИАБЕТОМ 2 ТИПА
}

\section{ОН. И. Ярема, А. И. Хомицкая, И. П. Савченко, Л. В. Радецкая, Л. В. Наумова, О. И. Коцюба}

\author{
ГВУЗ «Тернопольский государственный медицинский университет имени И. Я. Горбачевского \\ МЗ Украины»
}

РЕЗЮМЕ. Использование альфа-липоевой кислоты (а-ЛК) у больных со стабильной ишемической болезнью сердца (ИБС) с диабетической полинейропатией нижних конечностей (ДПНК) значительно повышает кислородное обеспечение периферических тканией.

Целью работы было повысить эффективность комплексного лечения ДПНК у больных со стабильной ИБС с сопутствующим СД 2 типа.

Материал и методы. Обследовано 54 больных со стабильной ИБС с сопутствующим СД 2 типа, осложненным ДПНК. Проведены эхокардиоскопия, оценка неврологических симптомов, исследование чувствительностей, а также оценка параметров оксигенации артериальной и венозной крови. Все больные получали стандартную терапию стабильной ИБС и а-ЛК в суточной дозе 600 мг на протяжении 1 месяца. 
Огляди літератури, оригінальні дослідження, погляд на проблему

Результаты. Комплексное применение а-ЛК со стандартной терапией стабильной ИБС значительно улучшает неврологическую симптоматику ДПНК и кислородное обеспечение тканей нижних конечностей.

КЛючЕВЫЕ СЛОВА: стабильная ишемическая болезнь сердца; диастолическая дисфункция левого желудочка; сахарный диабет 2 типа; диабетическая полинейропатия нижних конечностей; оксигенация артериальной и венозной крови; альфа-липоевая кислота.

\section{THE EFFICIENCY OF STANDARD THERAPY AND ALPHA-LIPOIC ACID IN PATIENTS WITH STABLE ISCHEMIC HEART DISEASE WITH CONCOMITANT DIABETES MELLITUS TYPE 2 @N. I. Yarema, A. I. Khomitska, I. P. Savchenko, L. V. Radetska, \\ I. Horbachevsky Ternopil State Medical University}

SUMMARY. The use of a-lipoic acid in patients with stable ischemic heart disease (IHD) with diabetic neurophaty of lower extremities considerably promotes the oxygen providing of peripheral tissues.

The aim of the work was to promote efficiency of treatment of neurophaty for patients with stable IHD and concomitant type 2 diabetes mellitus.

Materials and Methods. 54 patients with stable IHD and concomitant type 2 diabetes mellitus, complicated neurophaty were inspected. Echocardioscopy, estimation of neurological symptoms, research of esthesiaes, and also estimation of parameters of oxigenation of arterial and venous blood were conducted. All patients got standard therapy of stable IHD and a-lipoic acid in day's dose 600 mgs during 1 month.

Results. Complex application of a-lipoic acid with standard therapy of stable IHD considerably improves the neurological symptomatology of neurophaty and oxygen providing of lower extremities.

KEY WORDS: stable ischemic heart disease; left ventricle diastolic dysfunction; diabetes mellitus type 2; diabetic neuropathy of the lower extremities; oxygenation of arterial and venous blood; alpha-lipoic acid.

Отримано 08.08.2017 